\title{
Oral Immunotherapy for Food Allergy
}

\section{Wood RA}

\author{
Pediatric Allergy and Immunology, Department of Pediatrics, Johns Hopkins University School of Medicine, \\ Baltimore, USA
}

J Investig Allergol Clin Immunol 2017; Vol. 27(3): 151-159

doi: 10.18176/jiaci.0143

\begin{abstract}
Food allergy is a potentially life-threatening condition with no approved therapies apart from avoidance and injectable epinephrine for treatment of acute allergic reactions. Oral immunotherapy (OIT) is an experimental treatment in which patients consume gradually increasing quantities of the food to which they are allergic in an attempt to induce some level of desensitization. While desensitization is possible in most patients, OIT carries significant risks for allergic reactions, and the ability to induce longer-term tolerance has not yet been established. This review focuses on selected studies of OIT for the treatment of common food allergies such as cow's milk, hen's egg, and peanut.
\end{abstract}

Key words: Food allergy. Oral immunotherapy. Cow's milk. Hen's egg. Peanut. Desensitization. Tolerance. Sustained unresponsiveness. Skin prick test (SPT). Immunoglobulin E (IgE). Omalizumab.

\section{Resumen}

La alergia alimentaria es una condición potencialmente mortal para la que no existen tratamientos aprobados, excepto la evitación y la epinefrina para tratar reacciones alérgicas graves. La inmunoterapia oral (OIT) es un tratamiento experimental en el cual los pacientes ingieren cantidades gradualmente crecientes del alimento al que son alérgicos, con el fin de inducir algún nivel de desensibilización. Si bien la desensibilización es posible en la mayoría de los pacientes, OIT conlleva riesgos importantes de reacciones alérgicas y la capacidad de inducir tolerancia a más largo plazo todavía no ha sido establecida. Este artículo de revisión se centra en una selección de estudios de OIT para el tratamiento de alergias a alimentos comunes, como son la leche de vaca, huevos de gallina y cacahuete.

Palabras clave: Alergia alimentaria. Inmunoterapia oral. Leche de vaca. Huevo de gallina. Cacahuete. Desensibilización. Tolerancia. Falta de respuesta sostenida. Prick test. Inmunoglobulina. Omalizumab. 


\section{Introduction}

Food allergy is now estimated to affect up to $8 \%$ of children and up to $2 \%-3 \%$ of adults in the United States of America [1,2], where cow's milk, hen's egg, peanut, tree nut, wheat, soy, fish, and shellfish are the foods most often associated with food allergy [2]. Food allergy is potentially life-threatening and has a major impact on quality of life $[3,4]$. Avoidance is currently the only approved therapy, and, although effective, avoidance diets can be difficult and may also put children at risk of nutritional deficiencies and impaired growth $[5,6]$. While at least $80 \%$ of milk- and eggallergic children are expected to achieve natural tolerance to these foods by adulthood, only $15 \%-20 \%$ of peanut- or tree nut-allergic individuals "outgrow" their allergies [7]. Peanut allergy is common in developed countries, affecting $1 \%-2 \%$ of children in the United States of America [4,8], and peanut is implicated in over half of all food allergy-related deaths in the United States of America [9,10]. Effective therapies for peanut and other common food allergies are therefore highly desirable.

\section{What is Oral Immunotherapy?}

Oral immunotherapy (OIT) involves mixing an allergenic food into a vehicle and consuming it in gradually increasing doses [11]. OIT protocols vary in the type of food and vehicle used, with some using commercially available foods in their natural forms (eg, liquid milk or peanut flour), while others use specifically prepared products such as dehydrated egg white. Currently, although OIT essentially uses food materials, research studies in the United States of America require investigational new drug approval, and forms of therapy regulated by the United States Food and Drug Administration require additional standards and safeguards. For example, allergenic proteins must be identified and quantified, and the product must be shown to be free of microbial contaminants.

Most OIT protocols include an initial escalation phase, followed by a dose build-up phase and maintenance phases, which may vary considerably depending on the study (Figure) [11]. The initial escalation phase is typically conducted over 1-2 days using rapid up-dosing, which starts from a very small dose (extremely unlikely to cause an adverse reaction) and progressing to a dose that is still likely safe for home administration. Generally, the initial doses are in microgram quantities of allergenic protein, which progress to several milligrams by the end of this phase. If well tolerated, the dose is escalated incrementally (usually biweekly or weekly) until a target maintenance dose is reached or the patient reaches dose-limiting symptoms. There is considerable variation between studies regarding the target maintenance dose, which ranges from $300 \mathrm{mg}$ to $4000 \mathrm{mg}$. Maintenance therapy continues with daily administration in the home, and the length of maintenance therapy is heterogeneous, lasting from a few months to several years [12]. The Table illustrates some of the variability in study design in terms of maintenance dosing, length of therapy, and outcomes.

\section{Efficacy of OIT}

The potential efficacy of food OIT depends on the defined endpoints, including the ability to tolerate the treatment, the induction of a transient state of desensitization, and/or the development of a more durable state of clinical tolerance, which is often referred to as sustained unresponsiveness (SU) $[13,14]$. Desensitization is defined as a temporary increase in the threshold for reactivity, with maintenance of the desensitized state requiring continued consumption of the allergenic protein to prevent the reappearance of reactivity. In some trials, patients who are successfully desensitized are then required per protocol to restrict the allergenic food from their diet for a period of weeks to months, after which another oral food challenge is conducted to determine whether or not they have achieved SU. While all studies have demonstrated that the majority of patients treated with OIT can be successfully desensitized to a particular food, SU is less commonly achieved. This lack of sustained protection against allergic

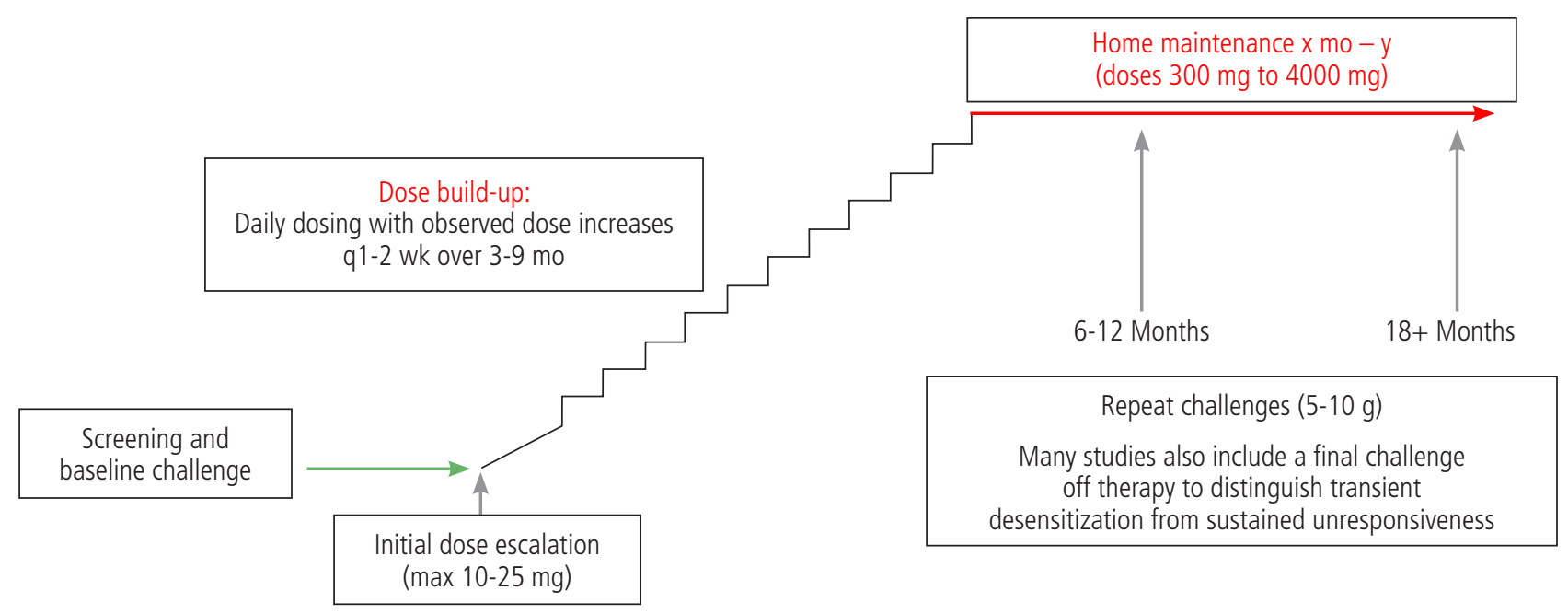

Figure. Typical approach to food OIT. 
Table. Representative OIT Trials

\begin{tabular}{|c|c|c|c|c|c|c|}
\hline Author & Year & Design & $\begin{array}{c}\text { Patient } \\
\text { Age }\end{array}$ & $\begin{array}{l}\text { Maintenance } \\
\text { Dose }\end{array}$ & Duration & Conclusions \\
\hline \multicolumn{7}{|l|}{ Peanut } \\
\hline Jones et al [18] & 2009 & Open-label & $1-16$ & $1800 \mathrm{mg}$ & 36 months & $93 \%$ passed $3.9 \mathrm{~g}$ peanut $\mathrm{OFC}$ \\
\hline Blumchen et al [20] & 2010 & $\begin{array}{c}\text { Randomized } \\
\text { open-label }\end{array}$ & $3-14$ & $500 \mathrm{mg}$ & $\begin{array}{l}\text { 7-day rush escalation, } \\
8 \text { weeks maintenance }\end{array}$ & $\begin{array}{l}64 \% \text { reached their maintenance } \\
\text { dose of } 500 \mathrm{mg} \text { peanut }\end{array}$ \\
\hline Varshney et al [21] & 2011 & $\begin{array}{l}\text { Randomized, } \\
\text { placebo-controlled }\end{array}$ & $3-11$ & $2000 \mathrm{mg}$ & 48 weeks & $84 \%$ passed $5000 \mathrm{mg}$ peanut $\mathrm{OFC}$ \\
\hline Anagnostou et al [22] & 2011 & Open-label & $4-18$ & $800 \mathrm{mg}$ & 32 weeks & $64 \%$ tolerated $6.6 \mathrm{~g} \mathrm{OFC}$ \\
\hline Anagnostou et al [23] & 2014 & $\begin{array}{l}\text { Randomized, } \\
\text { placebo-controlled }\end{array}$ & $7-16$ & $800 \mathrm{mg}$ & 26 weeks & $62 \%$ tolerated $1400 \mathrm{mg}$ challenge \\
\hline Vickery et al [14] & 2014 & Open-label & $1-16$ & $\begin{array}{l}\text { Up to } \\
4000 \mathrm{mg}\end{array}$ & Up to 5 years & $\begin{array}{l}\text { One month after OIT stopped, } 50 \% \\
\text { achieved SU to } 5000 \mathrm{mg} \text { OFC }\end{array}$ \\
\hline Narisety et al [60] & 2014 & $\begin{array}{l}\text { Randomized, } \\
\text { placebo-controlled }\end{array}$ & $7-13$ & $2000 \mathrm{mg}$ & 12 months & $\begin{array}{l}\text { Significantly greater increase in } \\
\text { OFC threshold in OIT versus SLIT, } \\
\text { low rate of SU }\end{array}$ \\
\hline Vickery et al [25] & 2016 & $\begin{array}{l}\text { Randomized } \\
\text { clinical trial }\end{array}$ & $\begin{array}{l}9-36 \\
\text { months }\end{array}$ & $\begin{array}{l}300 \mathrm{vs} \\
3000 \mathrm{mg}\end{array}$ & $\begin{array}{l}29 \text { months } \\
\text { (median) }\end{array}$ & $\begin{array}{l}\text { Overall, 91\% SU, no difference } \\
\text { between doses }\end{array}$ \\
\hline \multicolumn{7}{|l|}{ Egg } \\
\hline Buchanan et al [28] & 2007 & Open-label & $1-16$ & $0.3 \mathrm{~g}$ & 24 months & $\begin{array}{l}57 \% \text { passed } 8 \mathrm{~g} \text { OFC. } 29 \% \mathrm{SU} \\
\text { after } 3-4 \text { month period of avoidance }\end{array}$ \\
\hline Vickery et al [29] & 2010 & Open-label & $3-13$ & 0.3 to $3.6 \mathrm{~g}$ & $18-50$ months & 75\% SU 1 month after stopping OIT \\
\hline Burks et al [13] & 2012 & $\begin{array}{l}\text { Randomized, } \\
\text { placebo-controlled }\end{array}$ & $5-11$ & $1.6 \mathrm{~g}$ & 22 months & $\begin{array}{l}75 \% \text { passed } 10 \mathrm{~g} \text { OFC, but only } 28 \% \\
\text { with SU }\end{array}$ \\
\hline \multicolumn{7}{|l|}{ Milk } \\
\hline Longo et al [41] & 2008 & $\begin{array}{c}\text { Randomized } \\
\text { open-label }\end{array}$ & $5-17$ & $150 \mathrm{~mL}$ & $\begin{array}{l}\text { 10-day rush } \\
\text { escalation, } \\
1 \text { year maintenance }\end{array}$ & $\begin{array}{l}36 \% \text { tolerated } 150 \mathrm{~mL} \text { or more, } \\
54 \% \text { partially tolerant }(5-150 \mathrm{~mL})\end{array}$ \\
\hline Skripak et al [42] & 2008 & $\begin{array}{l}\text { Randomized, } \\
\text { placebo-controlled }\end{array}$ & $6-17$ & $\begin{array}{l}500 \mathrm{mg} \text { milk } \\
\text { protein }\end{array}$ & 23 weeks & $\begin{array}{l}\text { Median milk challenge threshold } \\
\text { rose from } 40 \mathrm{mg} \text { to } 5140 \mathrm{mg} \text { after OIT }\end{array}$ \\
\hline Martorell et al [46] & 2011 & $\begin{array}{l}\text { Randomized, } \\
\text { placebo-controlled }\end{array}$ & $2-3$ & $200 \mathrm{~mL}$ & 1 year & $90 \%$ showing complete desensitization \\
\hline Keet et al [48] & 2012 & $\begin{array}{l}\text { Randomized, } \\
\text { placebo-controlled }\end{array}$ & $6-17$ & $1000-2000 \mathrm{mg}$ & 60 weeks & $\begin{array}{l}70 \% \text { of patients receiving OIT } \\
\text { passed an } 8 \mathrm{~g} \mathrm{OFC,} \mathrm{SU} \mathrm{in} \mathrm{only} \\
40 \% \text { after } 6 \text { weeks }\end{array}$ \\
\hline
\end{tabular}

Abbreviations: OFC, open food challenge; OIT, oral immunotherapy; SLIT, sublingual immunotherapy; SU, sustained unresponsiveness.

symptoms has important implications for the future of oral immunotherapy and highlights the experimental nature of this treatment.

\section{Summary of Clinical Trials}

\section{Peanut OIT}

The use of subcutaneous peanut immunotherapy was first reported in 1992, but this approach was abandoned owing to an unacceptable systemic reaction rate [15]. Following 2 case reports of successful peanut OIT in 2006 [16,17], the first open-label trial of peanut OIT was published in 2009 in a prospective cohort study $[18,19]$, which showed successful desensitization and an overall reassuring safety profile, as well as immunologic changes consistent with those seen in other forms of immunotherapy. With a maintenance dose of $1800 \mathrm{mg}$ of peanut protein, $93 \%$ of the 29 patients who completed the protocol were able to tolerate an oral challenge with a cumulative dose of $3.9 \mathrm{~g}$ of peanut protein at 36 months [18]. In 2010, Blumchen et al [20] reported results for 23 children maintained on $500 \mathrm{mg}$ of peanut protein daily over a 9-week period, with a $60 \%$ success rate for passing an oral food challenge at the completion of treatment. 
In 2011, Varshney et al [21] reported the first multicenter, randomized, double-blind, placebo-controlled study of peanut OIT. The study included 28 patients aged 1 through 16 who underwent treatment with peanut or placebo with a daily maintenance dose of $4 \mathrm{~g}$ for about 1 year. Three patients withdrew early owing to adverse reactions; however, in a posttreatment double-blind, placebo-controlled food challenge (DBPCFC), the 16 patients who completed active OIT were able to ingest a maximum cumulative dose of $5 \mathrm{~g}$ of peanut protein ( $\sim 16$ peanuts) compared with the placebo group of 9 patients, who tolerated a median of $280 \mathrm{mg}$. The study also showed a significant decrease in skin test responses, as well as changes in serum IL-5 and IL-13 levels and $\mathrm{CD}^{+} \mathrm{CD} 25^{+} \mathrm{FoxP}^{+}$regulatory $\mathrm{T}$ cells in the active group compared with the placebo group.

In 2011, Anagnostou et al [22] reported results from a prospective cohort study of peanut OIT, in which 22 children received a daily maintenance dose of $800 \mathrm{mg}$ of peanut protein for 32 weeks. The authors demonstrated a significant increase in the peanut challenge threshold, with $86 \%$ of patients tolerating up-dosing and 14/22 (64\%) tolerating $6.6 \mathrm{~g}$ of peanut protein at the completion of treatment. In 2014, the same group completed a randomized controlled trial (RCT) with peanut OIT at a maintenance dose of $800 \mathrm{mg}$ [23]. In the first phase, each arm underwent 26 weeks of peanut OIT versus peanut avoidance, after which patients underwent a food challenge to $1400 \mathrm{mg}$ of peanut protein. In the active OIT group, 24 of 39 participants $(62 \%)$ had no reaction compared with no participants in the control group. The second phase allowed participants in the control group to receive active peanut OIT, with $84 \%$ of the active group at the end of the first phase and $91 \%$ of the control group at the end of the second phase able to tolerate daily ingestion of $800 \mathrm{mg}$ protein for 26 weeks.

The first study of SU following peanut OIT was published in 2014 [14]. Twenty-four patients aged 1 to 16 years completed OIT with maintenance dosing of $4000 \mathrm{mg}$ of peanut protein for up to 5 years. One month after stopping OIT, $50 \%$ of the patients demonstrated SU to a $5000-\mathrm{mg}$ oral challenge. Patients demonstrating SU were also found to have greater evidence of immunomodulation, with smaller wheals, lower peanut IgE levels, including Ara h 1 and Ara h 2, and lower ratios of peanut-specific IgE/total IgE. In another study that was designed primarily to compare peanut sublingual immunotherapy (SLIT) with OIT, while OIT was far superior to SLIT, only 4 of 20 patients on OIT were shown to have SU [24].

In a more recent open-label RCT analyzing peanut OIT in a population aged 9 to 36 months [25], patients were randomized to goal maintenance doses of $300 \mathrm{mg} / \mathrm{d}$ or $3000 \mathrm{mg} / \mathrm{d}$. In the intentto-treat analysis, 29 of 37 patients (78\%) achieved SU 4 weeks after completing treatment, with similar rates in the 300-mg group $(85 \%)$ and the 3000 -mg group $(71 \%)$ after a median treatment period of 29 months. Per protocol, 29 of 32 patients (91\%) achieved SU. It was also reassuring that the therapy was well tolerated, even in children of such a young age.

\section{Egg OIT}

Two early studies from Patriarca et al [26,27] reported on small numbers of patients treated with egg OIT, demonstrating successful desensitization in most patients. In another early trial, Buchanan et al [28] reported on 7 children aged 14 months to 7 years who received 24 months of egg OIT at a maintenance dose of $300 \mathrm{mg}$ of daily, with $57 \%$ passing an oral food challenge at completion of treatment. In a follow-up study at the same center, patients treated with a higher, individualized dose (median $2400 \mathrm{mg}$ ) for a median of 33 months had an SU rate of $75 \%$ (6 of 8 patients) 1 month after stopping treatment [29].

In one of the first randomized OIT trials, Staden et al [30] reported on 45 children who were treated with either egg or milk OIT, with maintenance dosing of $1.6 \mathrm{~g} / \mathrm{d}$ or $3.5 \mathrm{~g} / \mathrm{d}$, respectively, or an avoidance diet as a control. Eleven of the patients were egg-allergic. Although the milk and egg results were not reported separately, after a median of 21 months of therapy, 16/25 (64\%) were able to introduce the allergenic food into their diet, 9 with complete tolerance and 7 with partial tolerance, compared with 7 of 20 children (35\%) in the control group. Morisset et al [31] also published a randomized study of 60 children with milk allergy and 90 children with egg allergy. Patients were randomized to OIT or allergen avoidance, and after 6 months of treatment, $69 \%$ of those receiving egg OIT were successfully desensitized.

In 2012, Burks et al [13] reported results from the first multicenter, double-blind, randomized, placebo-controlled trial of egg OIT in which 55 patients aged 5-11 years were treated with a maintenance dose of $2 \mathrm{~g}$ of egg protein, with egg DBPCFCs performed at 10 and 22 months. For those who did not experience a reaction at the 22 -month challenge, OIT was discontinued for 6-8 weeks with a repeat food challenge to test for SU. At the 10-month DBPCFC, none of the placebo patients $(n=15)$ were desensitized compared with $55 \%$ of those treated with active OIT. After 22 months of OIT, 30 of 40 patients $(75 \%)$ were effectively desensitized, but only $11(28 \%)$ demonstrated SU on rechallenge 6 to 8 weeks later.

Other studies of egg OIT included the small RCTs by Dello Iacono et al and Meglio et al, who reported desensitization rates of $80 \%-90 \%$ in children with severe egg allergy, and 2 studies using rush protocols with desensitization induced in as few as 5 days [32-35].

\section{Milk OIT}

As with egg, Patriarca et al [26,27] performed 2 smallscale trials and reported the first studies on milk OIT, with desensitization rates of $65.5 \%$ and $100 \%$. In 2004, Meglio et al [36] performed a pilot study of 21 children treated with 6 months of OIT that resulted in a $72 \%$ success rate of tolerating a target dose of $200 \mathrm{~mL}$ of cow's milk daily, with an additional $14 \%$ of patients achieving partial desensitization. Of note, after a 4-year follow up, $70 \%$ at least partially tolerated milk, with significant reductions in serum-specific cow's milk $\operatorname{IgE}$ and skin prick test results [37]. A number of other nonrandomized milk OIT studies also demonstrated overall success in achieving desensitization [38-40].

As noted above for egg OIT, the first RCT of milk OIT was reported by Staden et al [30]. In 2008, Longo et al [41] reported an RCT of 60 children with a history of severe cow's milk allergy and high CM-specific IgE levels who were randomized to milk OIT or avoidance. While all those in the control group failed the DBPCFC at the 1-year mark, $36 \%$ of treated patients 
passed the OFC and an additional 54\% were partially tolerant. The year 2008 also marked the first placebo-controlled OIT trial in a study of milk OIT by Skripak et al [42], who demonstrated a rise in the median milk challenge threshold from $40 \mathrm{mg}$ at baseline to $5140 \mathrm{mg}$ after just 3-4 months of treatment, with no change in the placebo group. An open-label follow-up study based on individualized, ongoing milk intake demonstrated the ability to tolerate from $1000 \mathrm{mg}$ to $16000 \mathrm{mg}$ (median 7000 with $33 \%$ tolerating $16000 \mathrm{mg}$ ) of cow's milk protein over 3 to 17 months of follow-up [43].

Other studies of milk OIT included those of Pajno et al [44] in 2010 , as well as a study from the same group in 2013 suggesting that maintenance dosing after desensitization is equally successful daily or twice weekly [45]. In 2011, Martorell et al [46] completed an RCT of 60 children aged 24 to 36 months and demonstrated desensitization in $90 \%$ at 1 year. In 2012, Salmivesi et al [47] reported the results of an RCT in school-aged children, showing similar effectiveness for milk OIT.

In 2012, Keet et al [48] also published an open-label RCT comparing milk OIT with SLIT. All patients were initially treated with SLIT, after which they were randomized to continue SLIT or switch to OIT. The study demonstrated greater efficacy with OIT, as well as a higher incidence of significant adverse effects. The study also examined SU after stopping therapy for 1 and 6 weeks, showing that only $40 \%$ of patients passed an OFC when treatment was discontinued for 6 weeks and that 2 lost protection in the first week off therapy. An additional follow-up report on 32 patients from the study by Keet et al [49] on milk OIT showed that only $31 \%$ of patients appeared to be fully milk-tolerant 3 to 5 years after completing treatment, with many patients appearing to lose tolerance after successfully completing treatment, even some with demonstrated SU.

Over the past decade, many patients with milk allergy have been shown to tolerate milk that has been extensively heated; in addition, this exposure helps to promote eventual tolerance to unheated milk [50]. A recent study by Goldberg et al [51] sought to use this concept in patients who had been unable to tolerate milk OIT and were treated with OIT using baked milk. Unfortunately, in this highly select group of patients with severe milk allergy, only 3 of 14 achieved the primary outcome of tolerating $1.3 \mathrm{~g}$ of baked milk. Of the 11 treatment failures, 8 failed because of IgE-mediated reactions, and 3 did not complete the program because of non-IgE-mediated factors.

\section{OIT to Other Foods and Multiallergen OIT}

While most research to date has focused on milk, egg, and peanut, there is great interest in the potential to treat other common food allergies. Studies are currently ongoing using OIT to treat allergy to wheat, tree nut, fish, and possibly other food allergens. A recent study by Sato et al [52] investigated the efficacy of OIT in patients with wheat-induced anaphylaxis. The treatment was open-label with a historical control group of untreated patients, and the dose was $200 \mathrm{~g}$ of Japanese wheat noodles that contained $5.2 \mathrm{~g}$ of wheat protein. The target dose was achieved by 16 of the 18 patients, 11 of whom (61.1\%) passed an OFC to assess SU 2 weeks later. The authors concluded that even in patients with very severe wheat allergy, OIT using boiled noodles was safe and effective [53].
There is also interest in the potential to treat multiple food allergies simultaneously, since so many children are allergic to more than 1 food. Numerous OIT studies with multiple food allergens are currently underway, some with and some without coadministration of omalizumab. To date, preliminary data from one study demonstrated similar reaction rates and efficacy comparing monotherapy with peanut to OIT based on up to 5 foods [54], while a second Phase 1 study demonstrated successful desensitization to multiple foods using rush OIT after pretreatment with omalizumab. Reaction rates were relatively low (median of 3.2 reactions per 100 doses) [55].

\section{Immunologic Changes With OIT}

The mechanisms by which OIT induces desensitization, and possibly longer-term effects, remain under active investigation. Studies have consistently demonstrated specific immunologic changes, including increases in food-specific IgG4 and decreased basophil and mast cell responsiveness $[13,14,18,56]$. Some studies have shown alterations in the binding pattern of antigen to antigen-specific IgE, either by reduction in the diversity of epitope recognition or altered IgE affinity [57]. After 6-12 months of OIT, there appears to be a shift away from $\mathrm{T}_{\mathrm{H}} 2$ cytokine production towards a proinflammatory profile characterized by increased production of IL- $1 \beta$ and TNF- $\alpha$ [18]. Syed et al demonstrated increased function of antigen-specific $\mathrm{CD} 4{ }^{+} \mathrm{CD} 25^{+}$FoxP $3^{+}$ regulatory $\mathrm{T}$ cells following OIT, thus supporting the theory of active suppression of immune responses [56,58].

Gorelik et al [59] studied the mechanisms and duration of suppression of immune responses during peanut immunotherapy reported in the study by Narisety et al [60] and found that spontaneous and allergen-induced basophil reactivity, including IL-4 production, were suppressed during dose escalation and after 6 months of maintenance dosing. Many markers of immunologic suppression reversed after withdrawal of immunotherapy and, more surprisingly, in some cases during ongoing maintenance therapy. The authors concluded that while both peanut OIT and SLIT induce rapid suppression of basophil effector functions, dendritic cell activation, and $\mathrm{T}_{\mathrm{H}} 2$ cytokine responses during the initial phases of immunotherapy, in many patients suppression appeared to be transient.

Begin et al [61] addressed changes in allergen-specific T-cell phenotypes during immunotherapy. While prior studies have shown an overall skewing of the pathological $\mathrm{T}_{\mathrm{H}} 2$ response toward a normal $\mathrm{T}_{\mathrm{H}} 1$ or regulatory $\mathrm{T}$-cell response, questions have been raised about the specificity of this approach and whether these changes result from a reprogramming of existing allergen-specific clones (re-education hypothesis) or from their replacement by different clones to determine the dominant response (replacement hypothesis). The authors undertook next-generation sequencing of peanut-proliferative TCR $\beta$ in patients undergoing peanut OIT and found an extremely diversified polyclonal response with a very small fraction of consistent clones over time.

\section{Safety of OIT}

Adverse reactions are very common in OIT, with rates that are similar for each of the foods studied to date. Reactions are 
generally mild, and local symptoms such as oral itching are most common. Abdominal pain is the most common symptom leading to withdrawal from treatment, and moderate reactions such as wheezing, vomiting, and urticaria occur in a small percentage of cases. However, given that doses are given daily over an extended period of treatment, the risk for each patient is substantial. For example, in a study of milk OIT in young children, $47 \%$ developed moderate reactions over the course of treatment [46]. More severe reactions requiring treatment with epinephrine and $\beta$-agonists are most common during dose escalation but can also occur during maintenance therapy $[24,41,42,44,46]$. Wasserman et al [62] reported that 95 reactions requiring epinephrine occurred during peanut OIT in 352 patients. It is especially concerning that most severe reactions occur unpredictably, with a dose that has previously been tolerated, and that they are often associated with cofactors such as infection, exercise, anxiety, or allergen coexposure $[19,23,42,43]$.

A major impediment to moving these treatments to clinical practice is the high percentage of patients who cannot tolerate OIT. Overall, $10 \%-20 \%$ of patients drop out of OIT trials, with rates as high as $36 \%$. While some participants withdraw owing to anaphylaxis or other acute reactions, the vast majority of withdrawals are due to chronic abdominal pain. Eosinophilic esophagitis has been documented in some of these cases, and it is not clear how frequently undiagnosed disease may complicate OIT $[63,64]$. Further studies aimed at minimizing adverse reactions are therefore critically important if these treatments are to be moved forward for use in clinical practice.

\section{Adjunctive Therapies}

Several potential adjunctive therapies to OIT have been studied, with the goal of improving both safety and efficacy. Two initial pilot studies have examined the use omalizumab in combination with OIT, one with milk and the other with peanut $[65,66]$. In both cases, it is suggested that OIT can be escalated more rapidly when combined with omalizumab, although adverse reactions are still relatively common.

Two more recent RCTs also studied the adjunctive effects of omalizumab. In the first, Wood et al [67] studied the addition of omalizumab or placebo to open-label milk OIT. At the completion of treatment, $88.9 \%$ of the omalizumab-treated patients and $71.4 \%$ of the placebo-treated patients passed the 10 -g "desensitization" OFC $(P=.18)$. Two months later, SU was demonstrated in $48.1 \%$ in the omalizumab group and $35.7 \%$ in the placebo group $(P=.42)$. Adverse reactions were significantly reduced during OIT escalation in omalizumabtreated patients with regard to the percentage of doses with symptoms $(2.1 \%$ vs $16.1 \%, P=.0005)$, dose-related reactions requiring treatment $(0.0 \%$ vs $3.8 \%, P=.0008)$, and doses required to achieve maintenance ( 198 vs $225, P=.008$ ). The authors concluded that omalizumab led to improvements safety but not efficacy.

In the second study, open-label omalizumab was administered in a placebo-controlled study of peanut OIT [68]. After 12 weeks of treatment with omalizumab, patients underwent a rapid 1-day desensitization of up to $250 \mathrm{mg}$ of peanut protein, followed by weekly increases up to $2000 \mathrm{mg}$.
The median peanut dose tolerated on the initial desensitization day was $250 \mathrm{mg}$ for omalizumab-treated patients compared with $22.5 \mathrm{mg}$ for placebo-treated patients. Subsequently, 79\% of those receiving omalizumab tolerated $2000 \mathrm{mg}$ of peanut protein 6 weeks after stopping omalizumab compared with $12 \%$ of those receiving placebo $(P<.01)$. Reaction rates were not significantly lower in omalizumab-treated patients than in placebo-treated patients (odds ratio, $0.57 ; P=.15$ ), although omalizumab-treated patients were exposed to much higher peanut doses. The authors concluded that omalizumab enables patients with peanut allergy to be rapidly desensitized and that in most cases, this desensitization is sustained after omalizumab is discontinued.

It has also been suggested that probiotics may have adjuvant effects for inhalant allergen immunotherapy [69]. Tang et al [70] expanded this concept to food immunotherapy with a trial adding the probiotic Lactobacillus rhamnosus to peanut OIT or placebo. The primary outcome was induction of possible SU 2 to 5 weeks after discontinuing OIT, which was achieved in $82.1 \%$ of those receiving OIT and $3.6 \%$ of those receiving placebo. While these results are limited by the fact that the probiotic treatment was not placebo-controlled and the period off treatment was as short as 2 weeks, the proportion of patients achieving SU was higher than in other studies, thus raising the possibility that probiotics may truly enhance this effect.

Case reports and small open-label trials have been conducted with a number of other adjunctive therapies, including interferon gamma, ketotifen, and leukotriene receptor antagonists [71-75]. In 2013, a randomized single-blind placebo-controlled study of 6 patients undergoing peanut OIT showed that premedication with ketotifen at $2 \mathrm{mg}$ twice daily might reduce the incidence of gastrointestinal symptoms during active OIT [73]. Furthermore, Takahashi et al [74] studied the use of montelukast with OIT in a retrospective study of 5 children, where leukotriene receptor antagonists appeared to help patients reach their target dose. Each of these possible adjunctive therapies requires further study.

\section{Future Considerations/Conclusions}

Food allergy is common and potentially life-threatening. Despite the significant impact of food allergy on patients and health care systems, there are currently no approved therapies for food allergy apart from strict avoidance. Milk, egg, and peanut OIT studies have consistently shown successful desensitization, although longer-lasting tolerance does not appear likely at this stage of investigation. Further mechanistic studies are needed to improve our understanding of the immunologic changes induced by OIT and to identify biomarkers of response. Safety is a significant concern, as adverse events are common during OIT, thus limiting its use in some patients. Incorporation of novel therapies such as modified food allergens, probiotics, and other immunomodulator therapies in conjunction with OIT is underway with the goals of improving both safety and efficacy. Larger, well-designed, randomized, placebo-controlled trials are needed to determine the efficacy and short- and long-term safety of OIT before it can be implemented in general clinical practice. 


\section{Funding}

The author declares that no funding was received for the present study.

\section{Conflicts of Interest}

The author declares that he has received research support from the National Institutes of Health, Astellas, Aimmune Therapeutics, DBV, and HAL-Allergy.

\section{References}

1. Gupta RS, Springston EE, Warrier MR, Smith B, Kumar R, Pongracic J, Holl JL. The prevalence, severity, and distribution of childhood food allergy in the United States. Pediatrics. 2011;128(1):e9-17.

2. Chafen JJ, Newberry SJ, Riedl MA, Bravata DM, Maglione M, Suttorp MJ, Sundaram V, Paige NM, Towfigh A, Hulley BJ, Shekelle PG. Diagnosing and managing common food allergies: a systematic review. JAMA. 2010;303(18):1848-56.

3. Lieberman JA, Sicherer SH. Quality of life in food allergy. Curr Opin Allergy Clin Immunol. 2011;11(3):236-42.

4. Sicherer SH, Sampson HA. Food allergy. J Allergy Clin Immunol. 2010;125(2 Suppl 2):S116-25.

5. Kim J, Kwon J, Noh G, Lee SS. The effects of elimination diet on nutritional status in subjects with atopic dermatitis. Nutr Res Pract. 2013;7(6):488-94

6. Hobbs CB, Skinner AC, Burks AW, Vickery BP. Food allergies affect growth in children. J Allergy Clin Immunol Pract. 2015;3(1):133-4 e1.

7. Nowak-Wegrzyn A, Sampson HA. Future therapies for food allergies. J Allergy Clin Immunol. 2011;127(3):558-73; quiz 74-5.

8. Nurmatov U, Venderbosch I, Devereux G, Simons FE, Sheikh A. Allergen-specific oral immunotherapy for peanut allergy. Cochrane Database Syst Rev. 2012;9:CD009014.

9. Bock SA, Munoz-Furlong A, Sampson HA. Further fatalities caused by anaphylactic reactions to food, 2001-2006. J Allergy Clin Immunol. 2007;119(4):1016-8.

10. Wensing M, Penninks AH, Hefle SL, Akkerdaas JH, van Ree R, Koppelman SJ, Bruijnzeel-Koomen CA, Knulst AC. The range of minimum provoking doses in hazelnut-allergic patients as determined by double-blind, placebo-controlled food challenges. Clin Exp Allergy. 2002;32(12):1757-62.

11. Wood RA. Food allergen immunotherapy: Current status and prospects for the future. J Allergy Clin Immunol. 2016;137(4):973-82.

12. Kulis $M$, Wright BL, Jones SM, Burks AW. Diagnosis, Management, and Investigational Therapies for Food Allergies. Gastroenterology. 2015.

13. Burks AW, Jones SM, Wood RA, Fleischer DM, Sicherer SH, Lindblad RW, Dawson P, Berin C, Fleischer DM, Leung DY, Plaut M, Sampson HA; Consortium of Food Allergy Research. Oral immunotherapy for treatment of egg allergy in children. New Engl J Med. 2012;367(3):233-43.

14. Vickery BP, Scurlock AM, Kulis $M$, Steele PH, Kamilaris J, Berglund JP, Burk C, Hiegel A, Carlisle S, Christie L, Perry TT, Pesek RD, Sheikh S, Virkud Y, Smith PB, Shamji MH, Durham SR, Jones SM, Burks AW. Sustained unresponsiveness to peanut in subjects who have completed peanut oral immunotherapy. J Allergy Clin Immunol. 2014;133(2):468-75.

15. Oppenheimer JJ, Nelson HS, Bock SA, Christensen F, Leung DY. Treatment of peanut allergy with rush immunotherapy. J Allergy Clin Immunol. 1992;90(2):256-62.

16. Patriarca G, Nucera E, Pollastrini E, De Pasquale T, Lombardo C, Buonomo A, Roncallo C, Pecora V, Musumeci S, Altomonte G, Alonzi C, Schiavino D, Gasbarrini G. Oral rush desensitization in peanut allergy: a case report. Dig Dis Sci. 2006;51(3):471-3.

17. Mansfield L. Successful oral desensitization for systemic peanut allergy. Ann Allergy Asthma Immunol. 2006;97(2):266-7.

18. Jones SM, Pons L, Roberts JL, Scurlock AM, Perry TT, Kulis $M$, Shreffler WG, Steele P, Henry KA, Adair M, Francis JM, Durham $S$, Vickery BP, Zhong $X$, Burks AW. Clinical efficacy and immune regulation with peanut oral immunotherapy. J Allergy Clin Immunol. 2009;124(2):292-300, e1-97.

19. Hofmann AM, Scurlock AM, Jones SM, Palmer KP, Lokhnygina Y, Steele PH, Kamilaris J, Burks AW. Safety of a peanut oral immunotherapy protocol in children with peanut allergy. J Allergy Clin Immunol. 2009;124(2):286-91, 91 e1-6.

20. Blumchen K, Ulbricht H, Staden U, Dobberstein K, Beschorner J, de Oliveira LC, Shreffler WG, Sampson HA, Niggemann B, Wahn U, Beyer K. Oral peanut immunotherapy in children with peanut anaphylaxis. J Allergy Clin Immunol. 2010;126(1):8391 e1.

21. Varshney $P$, Jones SM, Scurlock AM, Perry TT, Kemper $A$, Steele P, Hiegel A, Kamilaris J, Carlisle S, Yue X, Kulis M, Pons L, Vickery B, Burks AW. A randomized controlled study of peanut oral immunotherapy: clinical desensitization and modulation of the allergic response. J Allergy Clin Immunol. 2011;127(3):654-60.

22. Anagnostou K, Clark A, King Y, Islam S, Deighton J, Ewan P. Efficacy and safety of high-dose peanut oral immunotherapy with factors predicting outcome. Clin Exp Allergy. 2011;41(9):1273-81.

23. Anagnostou K, Islam S, King Y, Foley L, Pasea L, Bond S, Palmer C, Deighton J, Ewan P, Clark A. Assessing the efficacy of oral immunotherapy for the desensitisation of peanut allergy in children (STOP II): a phase 2 randomised controlled trial. Lancet. 2014;383(9925):1297-304.

24. Narisety SD, Frischmeyer-Guerrerio PA, Keet CA, Gorelik M, Schroeder J, Hamilton RG, Wood RA. A randomized, doubleblind, placebo-controlled pilot study of sublingual versus oral immunotherapy for the treatment of peanut allergy. J Allergy Clin Immunol. 2015;135(5):1275-82.e1-6.

25. Vickery BP, Berglund JP, Burk CM, Fine JP, Kim EH, Kim JI, Keet CA, Kulis M, Orgel KG, Guo R, Steele PH, Virkud YV, Ye P, Wright BL, Wood RA, Burks AW. Early oral immunotherapy in peanut-allergic preschool children is safe and highly effective. J Allergy Clin Immunol. 2017;139(1):173-81.e8.

26. Patriarca G, Nucera E, Roncallo C, Pollastrini E, Bartolozzi F, De Pasquale T, Buonomo A, Gasbarrini G, Di Campli C, Schiavino. Oral desensitizing treatment in food allergy: clinical and immunological results. Aliment Pharmacol Ther. 2003;17(3):459-65.

27. Patriarca G, Schiavino D, Nucera E, Schinco G, Milani A, Gasbarrini GB. Food allergy in children: results of a standardized protocol for oral desensitization. Hepatogastroenterology. 1998;45(19):52-8. 
28. Buchanan $A D$, Green $T D$, Jones $S M$, Scurlock $A M$, Christie $L$, Althage KA, Steele PH, Pons L, Helm RM, Lee LA, Burks AW. Egg oral immunotherapy in nonanaphylactic children with egg allergy. J Allergy Clin Immunol. 2007;119(1):199-205.

29. Vickery BP, Pons L, Kulis M, Steele P, Jones SM, Burks AW. Individualized IgE-based dosing of egg oral immunotherapy and the development of tolerance. Ann Allergy Asthma Immunol. 2010;105(6):444-50.

30. Staden U, Rolinck-Werninghaus C, Brewe $F$, Wahn $U$, Niggemann B, Beyer K. Specific oral tolerance induction in food allergy in children: efficacy and clinical patterns of reaction. Allergy. 2007;62(11):1261-9.

31. Morisset M, Moneret-Vautrin DA, Guenard L, Cuny JM, Frentz P, Hatahet R, Hanss Ch, Beaudouin E, Petit N, Kanny G. Oral desensitization in children with milk and egg allergies obtains recovery in a significant proportion of cases. A randomized study in 60 children with cow's milk allergy and 90 children with egg allergy. Eur Ann Allergy Clin Immunol. 2007;39(1):129 .

32. Meglio P, Giampietro PG, Carello R, Gabriele I, Avitabile S, Galli E. Oral food desensitization in children with IgE-mediated hen's egg allergy: a new protocol with raw hen's egg. Pediatr Allergy Immunol. 2013;24(1):75-83.

33. Itoh N, Itagaki Y, Kurihara K. Rush specific oral tolerance induction in school-age children with severe egg allergy: one year follow up. Allergol Int. 2010;59(1):43-51.

34. Dello lacono I, Tripodi S, Calvani M, Panetta V, Verga MC, Miceli Sopo S. Specific oral tolerance induction with raw hen's egg in children with very severe egg allergy: a randomized controlled trial. Pediatr Allergy Immunol. 2013;24(1):66-74.

35. Garcia Rodriguez R, Urra JM, Feo-Brito F, Galindo PA, Borja J, Gomez E, Lara P, Guerra F. Oral rush desensitization to egg: efficacy and safety. Clin Exp Allergy. 2011;41(9):1289-96.

36. Meglio P, Bartone E, Plantamura M, Arabito E, Giampietro PG. A protocol for oral desensitization in children with IgEmediated cow's milk allergy. Allergy. 2004;59(9):980-7.

37. Meglio P, Giampietro PG, Gianni S, Galli E. Oral desensitization in children with immunoglobulin E-mediated cow's milk allergy--follow-up at 4 yr and 8 months. Pediatr Allergy Immunol. 2008;19(5):412-9.

38. Zapatero L, Alonso E, Fuentes V, Martinez MI. Oral desensitization in children with cow's milk allergy. J Investig Allergol Clin Immunol. 2008;18(5):389-96.

39. Alvaro M, Giner MT, Vazquez M, Lozano J, Dominguez $O$, Piquer M, Días M, Jiménez R, Martín MA, Alsina L, Plaza AM. Specific oral desensitization in children with IgE-mediated cow's milk allergy. Evolution in one year. Eur J Pediatr. 2012;171(9):1389-95.

40. Sanchez-Garcia S, Rodriguez del Rio P, Escudero C, Garcia-Fernandez C, Ramirez A, Ibanez MD. Efficacy of oral immunotherapy protocol for specific oral tolerance induction in children with cow's milk allergy. Isr Med Assoc J. 2012;14(1):43-7.

41. Longo G, Barbi E, Berti I, Meneghetti R, Pittalis A, Ronfani $L$, Ventura A. Specific oral tolerance induction in children with very severe cow's milk-induced reactions. J Allergy Clin Immunol. 2008;121(2):343-7.

42. Skripak JM, Nash SD, Rowley H, Brereton NH, Oh S, Hamilton RG, Matsui EC, Burks AW, Wood RA. A randomized, double- blind, placebo-controlled study of milk oral immunotherapy for cow's milk allergy. J Allergy Clin Immunol. 2008;122(6):115460.

43. Narisety SD, Skripak JM, Steele P, Hamilton RG, Matsui EC, Burks AW, Wood RA. Open-label maintenance after milk oral immunotherapy for lgE-mediated cow's milk allergy. J Allergy Clin Immunol. 2009;124(3):610-2.

44. Pajno GB, Caminiti L, Ruggeri P, De Luca R, Vita D, La Rosa $M$, Passalacqua G. Oral immunotherapy for cow's milk allergy with a weekly up-dosing regimen: a randomized single-blind controlled study. Ann Allergy Asthma Immunol. 2010;105(5):376-81.

45. Pajno GB, Caminiti L, Salzano G, Crisafulli G, Aversa T, Messina MF, Wasniewska M, Passalacqua G. Comparison between two maintenance feeding regimens after successful cow's milk oral desensitization. Pediatr Allergy Immunol. 2013;24(4):376-81.

46. Martorell A, De la Hoz B, Ibanez MD, Bone J, Terrados MS, Michavila A, Plaza AM, Alonso E, Garde J, Nevot S, Echeverria L, Santana C, Cerdá JC, Escudero C, Guallar I, Piquer M, Zapatero L, Ferré L, Bracamonte T, Muriel A, Martínez MI, Félix R. Oral desensitization as a useful treatment in 2-year-old children with cow's milk allergy. Clin Exp Allergy. 2011;41(9):1297304.

47. Salmivesi S, Korppi M, Makela MJ, Paassilta M. Milk oral immunotherapy is effective in school-aged children. Acta Paediatr. 2013;102(2):172-6.

48. Keet $C A$, Frischmeyer-Guerrerio PA, Thyagarajan A, Schroeder JT, Hamilton RG, Boden S, Steele P, Driggers S, Burks AW, Wood RA. The safety and efficacy of sublingual and oral immunotherapy for milk allergy. J Allergy Clin Immunol. 2012;129(2):448-55, 55 e 1-5.

49. Keet CA, Seopaul S, Knorr S, Narisety S, Skripak J, Wood RA Long-term follow-up of oral immunotherapy for cow's milk allergy. J Allergy Clin Immunol. 2013;132(3):737-9 e6.

50. Leonard SA, Caubet JC, Kim JS, Groetch M, Nowak-Wegrzyn A. Baked milk- and egg-containing diet in the management of milk and egg allergy. J Allergy Clin Immunol Pract. 2015;3(1):13-23; quiz 4

51. Goldberg MR, Nachshon L, Appel MY, Elizur A, Levy MB, Eisenberg E, Sampson HA, Katz Y. Efficacy of baked milk oral immunotherapy in baked milk-reactive allergic patients. J Allergy Clin Immunol. 2015;136(6):1601-6.

52. Sato S, Utsunomiya T, Imai T, Yanagida N, Asaumi T, Ogura K, Koike Y, Hayashi N, Okada Y, Shukuya A, Ebisawa M.. Wheat oral immunotherapy for wheat-induced anaphylaxis. J Allergy Clin Immunol. 2015;136(4):1131-3e7.

53. Sato $S$, Yanagida N, Ogura K, Imai T, Utsunomiya T, likura K, Goto M, Asaumi T, Okada Y, Koike Y, Syukuya A, Ebisawa M. Clinical studies in oral allergen-specific immunotherapy: differences among allergens. Int Arch Allergy Immunol. 2014;164(1):1-9.

54. Begin P, Winterroth LC, Dominguez T, Wilson SP, Bacal L, Mehrotra A, Kausch B, Trela A, Hoyte E, O'Riordan G, Seki S, Blakemore A, Woch M, Hamilton RG, Nadeau KC. Safety and feasibility of oral immunotherapy to multiple allergens for food allergy. Allergy Asthma Clin Immunol. 2014;10(1):1.

55. Begin P, Dominguez T, Wilson SP, Bacal L, Mehrotra A, Kausch B, Trela A, Tavassoli M, Hoyte E, O'Riordan G, Blakemore A, Seki S, Hamilton RG, Nadeau KC. Phase 1 results of safety and tolerability 
in a rush oral immunotherapy protocol to multiple foods using Omalizumab. Allergy Asthma Clin Immunol. 2014;10(1):7.

56. Gorelik $M$, Narisety SD, Guerrerio AL, Chichester $K L$, Keet CA, Bieneman AP, Hamilton RG, Wood RA, Schroeder JT, Frischmeyer-Guerrerio PA. Suppression of the immunologic response to peanut during immunotherapy is often transient. J Allergy Clin Immunol. 2015;135(5):1283-92.

57. Vickery BP, Lin J, Kulis M, Fu Z, Steele PH, Jones SM, Scurlock AM, Gimenez G, Bardina L, Sampson HA, Burks AW. Peanut oral immunotherapy modifies $\lg$ E and $\lg G 4$ responses to major peanut allergens. J Allergy Clin Immunol. 2013;131(1):128-34 e1-3.

58. Syed A, Garcia MA, Lyu SC, Bucayu R, Kohli A, Ishida S, Berglund JP, Tsai M, Maecker H, O'Riordan G, Galli SJ, Nadeau KC. Peanut oral immunotherapy results in increased antigeninduced regulatory T-cell function and hypomethylation of forkhead box protein 3 (FOXP3). J Allergy Clin Immunol. 2014;133(2):500-10.

59. Gorelik M, Narisety SD, Guerrerio $A L$, Chichester $K L$, Keet CA, Bieneman AP, Hamilton RG, Wood RA, Schroeder JT, Frischmeyer-Guerrerio PA. Suppression of the immunologic response to peanut during immunotherapy is often transient. J Allergy Clin Immunol. 2015;135(5):1283-92.

60. Narisety SD, Frischmeyer-Guerrerio PA, Keet CA, Gorelik M, Schroeder J, Hamilton RG, Wood RA. A randomized, doubleblind, placebo-controlled pilot study of sublingual versus oral immunotherapy for the treatment of peanut allergy. J Allergy Clin Immunol. 2015;135(5):1275-82 e1-6.

61. Bégin P, Nadeau KC. Changes in peanut-specific T-cell clonotype with oral immunotherapy. J Allergy Clin Immunol. 2015;135(6):1636-8e3.

62. Wasserman RL, Factor JM, Baker JW, Mansfield LE, Katz Y, Hague AR, Paul MM, Sugerman RW, Lee JO, Lester MR, Mendelson LM, Nacshon L, Levy MB, Goldberg MR, Elizur A. Oral immunotherapy for peanut allergy: multipractice experience with epinephrine-treated reactions. J Allergy Clin Immunol Pract. 2014;2(1):91-6.

63. Sanchez-Garcia S, Rodriguez Del Rio P, Escudero C, MartinezGomez MJ, Ibanez MD. Possible eosinophilic esophagitis induced by milk oral immunotherapy. J Allergy Clin Immunol. 2012;129(4):1155-7.

64. Ridolo E, De Angelis GL, Dall'aglio P. Eosinophilic esophagitis after specific oral tolerance induction for egg protein. Ann Allergy Asthma Immunol. 2011;106(1):73-4.

65. Schneider LC, Rachid R, LeBovidge J, Blood E, Mittal M, Umetsu DT. A pilot study of omalizumab to facilitate rapid oral desensitization in high-risk peanut-allergic patients. J Allergy Clin Immunol. 2013;132(6):1368-74.

66. Nadeau KC, Schneider LC, Hoyte L, Borras I, Umetsu DT. Rapid oral desensitization in combination with omalizumab therapy in patients with cow's milk allergy. J Allergy Clin Immunol. 2011;127(6):1622-4.

67. Wood RA, Kim JS, Lindblad R, Nadeau K, Henning AK, Dawson P, Plaut M, Sampson HA. A randomized, double- blind, placebo-controlled study of omalizumab combined with oral immunotherapy for the treatment of cow's milk allergy. J Allergy Clin Immunol. 2016;137(4):1103-10.e1-11.

68. MacGinnitie AJ, Rachid R, Gragg H, Little SV, Lakin P, Cianferoni A, Heimall J, Makhija M, Robison R, Chinthrajah RS, Lee J, Lebovidge J, Dominguez T, Rooney C, Lewis MO, Koss J, BurkeRoberts E, Chin K, Logvinenko T, Pongracic JA, Umetsu DT, Spergel J, Nadeau KC, Schneider LC. Omalizumab facilitates rapid oral desensitization for peanut allergy. J Allergy Clin Immunol. 2017 Mar;139(3):873-881.

69. Van Overtvelt L, Moussu H, Horiot S, Samson S, Lombardi $V$, Mascarell $L$, van de Moer A, Bourdet-Sicard R, Moingeon $P$. Lactic acid bacteria as adjuvants for sublingual allergy vaccines. Vaccine. 2010;28(17):2986-92.

70. Tang MLK, Ponsonby AL, Orsini F, Tey D, Robinson M, Su EL, Licciardi P, Burks W, Donath S. Administration of a probiotic with peanut oral immunotherapy: A randomized trial. J Allergy Clin Immunol. 2015;135(3):737-44.e8.

71. Tang ML, Ponsonby AL, Orsini F, Tey D, Robinson M, Su EL, Licciardi P, Burks W, Donath S. Administration of a probiotic with peanut oral immunotherapy: A randomized trial. J Allergy Clin Immunol. 2015;135(3):737-44 e8.

72. Noh G, Lee SS. A pilot study of interferon-gamma-induced specific oral tolerance induction (ISOTI) for immunoglobulin E-mediated anaphylactic food allergy. J Interferon Cytokine Res. 2009;29(10):667-75.

73. Jagdis A, Berlin N, Barron C, Giruparajah $M$, Leader $N$, Maclachlan S, Sussman GL. Effect of ketotifen premedication on adverse reactions during peanut oral immunotherapy. Allergy Asthma Clin Immunol. 2014;10(1):36.

74. Takahashi M, Taniuchi S, Soejima K, Sudo K, Hatano Y, Kaneko K. New efficacy of LTRAs (montelukast sodium): it possibly prevents food-induced abdominal symptoms during oral immunotherapy. Allergy Asthma Clin Immunol. 2014;10(1):3.

75. Lee SJ, Noh G, Lee JH. In Vitro Induction of Allergen-Specific Interleukin-10-Producing Regulatory B Cell Responses by Interferon-gamma in Non-Immunoglobulin E-Mediated Milk Allergy. Allergy Asthma Immunol Res. 2013;5(1):48-54.

- Manuscript received April 2, 2017; accepted for publication April 2, 2017.

\section{Robert A Wood}

Director, Pediatric Allergy and Immunology

Department of Pediatrics

Johns Hopkins University School of Medicine

Baltimore, MD, USA

E-mail: rwood@jhmi.edu 